\title{
Evolutionary Perspective on Narmada Hominin Fossils
}

\author{
Anek R. Sankhyan ${ }^{1,2}$ \\ ${ }^{1}$ Anthropological Survey of India, Kolkata, India \\ ${ }^{2}$ Palaeo Research Society, Ghumarwin, India \\ Email: arsankhyan@gmail.com
}

How to cite this paper: Sankhyan, A. R. (2020). Evolutionary Perspective on Narmada Hominin Fossils. Advances in Anthropology, 10, 235-258.

https://doi.org/10.4236/aa.2020.103013

Received: July 24, 2020

Accepted: August 25, 2020

Published: August 28, 2020

Copyright (c) 2020 by author(s) and Scientific Research Publishing Inc. This work is licensed under the Creative Commons Attribution International License (CC BY 4.0).

http://creativecommons.org/licenses/by/4.0/

\begin{abstract}
Understanding of human evolution in South Asia primarily rests on a solitary calvarium (partial skullcap) from Hathnora in the central Narmada valley, but its disputed taxonomic status has blurred the picture. Early explorations (1983-1992) led to the discovery of 2-clavicles and a $9^{\text {th }}$ rib from Hathnora, but those were so tiny to fit with the calvarium, and fueled the debate whether the calvarium is of a dwarf or a pygmy. Further explorations conducted (2005-2010) brought out 6-femora, 3-humeri and 2-sacra. They were derived from different localities and bio-stratigraphic and archaeological contexts, and posed a challenge of association with the calvarium or with other unknown hominins. The present study is undertaken to address this problem, and the postcranial bones are sorted into possible morphotypes based on criteria of robustness, estimated sex and stature/body size under the control of their contexts. The study distinguished two major morphotypes which reflect the process of humanization in the central Narmada valley and a possible evolutionary scenario for South Asia. The earliest morphotype is a "robust tall hominin", recognized as a unique hybrid cf. H. heidelbergensis, represented by the calvarium and two femora. It appeared around $300-150 \mathrm{ka}$ in association with megaterrestrial fauna and late Acheulian tools-kit. The second morphotype is a "short and stocky" hominin, named Homo narmadensis Sp. Nov. This is hitherto unrecognized hominin represented by eight fossil bones in association with the "Upper Group fauna" and Middle to Upper Palaeolithic industry. It appeared about $150-100 \mathrm{ka}$ and continued to ca. $40 \mathrm{ka}$, and was the likely precursor to the "short-bodied" ancient populations of India, including the Andaman pygmy.
\end{abstract}

\section{Keywords}

Calvarium, Postcranial, Morphotypes, Bio-Stratigraphic, Archaeological Contexts, Evolution 


\section{Introduction}

Current understanding of human evolution in South Asia greatly owes to the central Narmada valley, which stands unique for gifting us unambiguous Middle to Late Pleistocene hominin fossils in association with numerous mammalian fauna and Palaeolithic implements (Figure 1). After a long century's wait, a discovery of a half skullcap (calvarium) (Sonakia, 1984) came from Hathnora in the year 1982 (Figure 2(1a)-(d)), which invigorated interest of many palaeoanthropologists and archaeologists in the Central Narmada valley. The author and a few associates from the Anthropological Survey of India (herein after called AnSI) initiated explorations at Hathnora and vicinity from 1983 through 1992. These resulted the discoveries of two clavicles and a $9^{\text {th }}$ rib (Figure 2: 2-4) from Hathnora, recognized by the author in 1995 and reported (Sankhyan, 1997a, 1997b, 2005). They shared the sex, age and locality of the calvarium, but were too tiny to go with a "large-headed" hominin, and created controversy whether the calvarium was of a "dwarf" or a "pygmy" (Sankhyan, 1999). An alternative model was also suggested to accommodate the both (van Heteren \& Sankhyan, 2009), since scholars did not favour the presence of a pygmy on Indian mainland. The debate prompted the Anthropological Survey of India to re-initiate fresh explorations and trial excavations in the central Narmada valley during 2005-2010 to seek new fossil materials.

\section{Bio-Stratigraphy and Dating}

The central Narmada valley is a trough basin between the Satpura and the Vindhya hills, filled with the Lower and Upper Group Quaternary Alluvium. But, owing to the discovery of the calvarium the Geological Survey of India initiated a multifarious systematic study (Tiwari \& Bhai, 1997) that re-classified the Quaternary Alluvium into seven formations. The oldest formations were known as the Pilikarar and Dhansi formations attributed to the Lower Pleistocene.

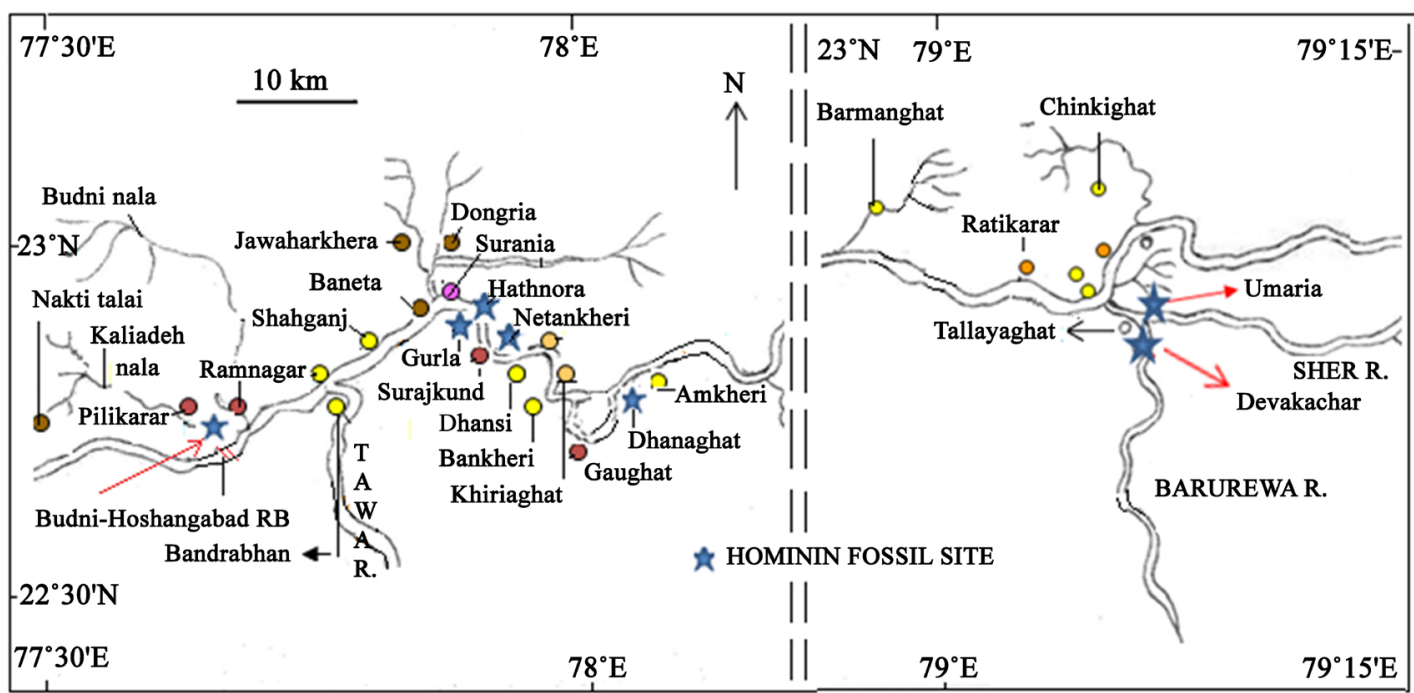

Figure 1. Map of central Narmada valley fossil localities showing the hominin sites with stars. 


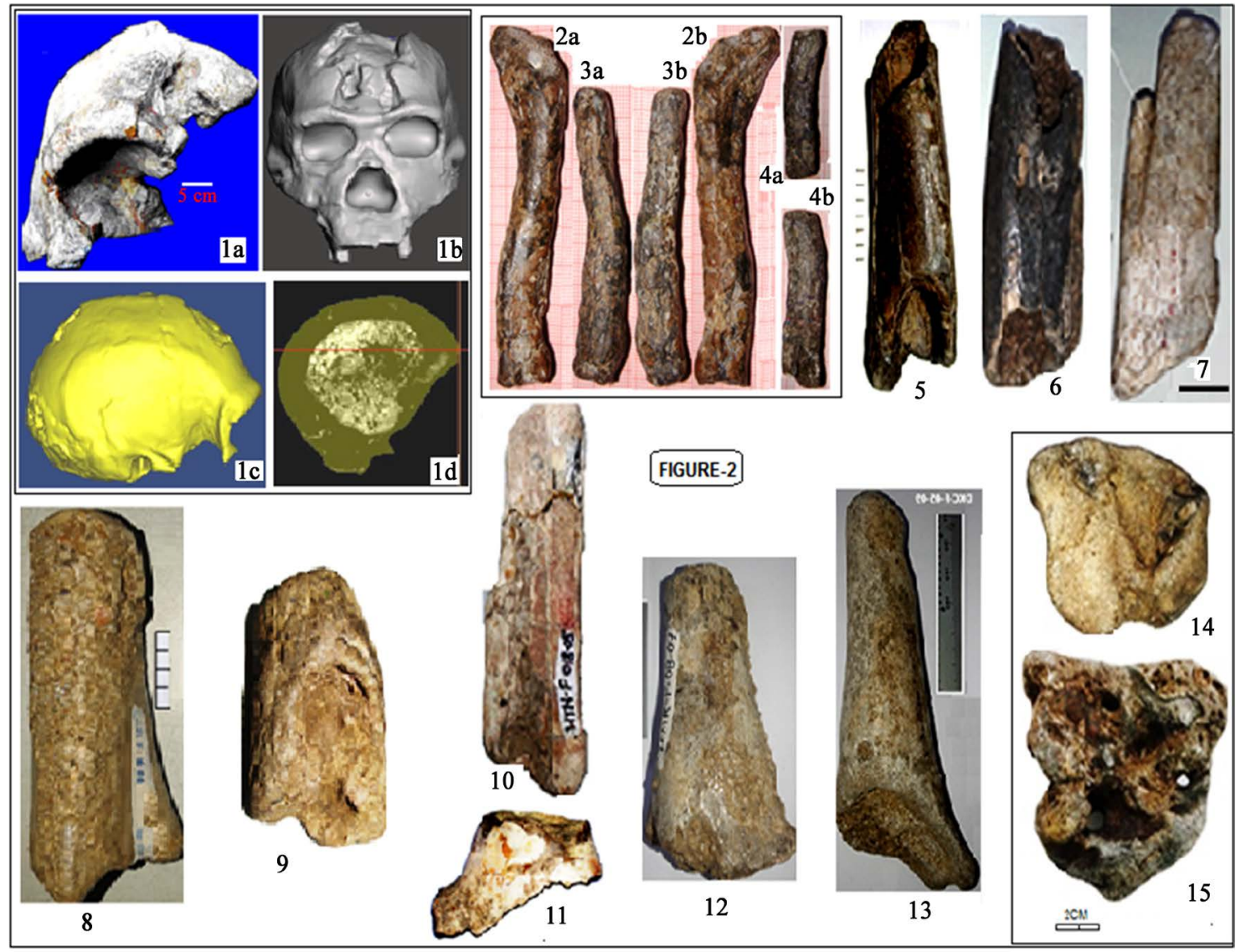

Figure 2. Narmada hominin fossils: 1. (1a)-(1d), different views of the calvarium; 2. (2a), (2b) right clavicle; 2. (3a), (3b), left clavicle, 2. (4a), (4b) $9^{\text {th }}$ rib; 5 - 7: humeri from Netankheri, Dhanaghat and Budnighat; 8 - 13 femora: 8. Gurla, 9. Netankheri, 10 - 11 Hathnora; 12 Umaria, 13 Devakachar; 14 - 15 female and male sacra from Netankheri.

Studies revealed that the Dhansi immediately overlays the palaeomagnetic reversal at ca $730 \mathrm{ka}$ (Agrawal et al., 1988; Rao et al., 1997), such that the Dhansi was succeeded by the Middle Pleistocene Surajkund formation which had yielded human fossils. It was succeeded by the overlying Baneta and Hirdepur formations of the Late Pleistocene; the latter contained a layer of the Youngest Toba Ash (YTA) and thus provided a definite upper datum of ca.75ka (Chesner et al., 1991; Acharyya \& Basu, 1993; Westgate et al., 1998). Other overlying formations were identified as Janbasa and Ramnagar mid-Holocene formations, capped by the black cotton soil.

The hominin calvarium site lies in the west of Hathnora village located $77^{\circ} 53^{\prime} \mathrm{N}: 22^{\circ} 52^{\prime} \mathrm{E}$ on the right bank of the Narmada, $22 \mathrm{~km}$ North-East of Hoshangabad town. The calvarium had come from the yellow sands of the Surajkund formation concealed by the older cemented sheet-gravel, called "Boulder Conglomerate". There are three visible successive consolidated cemented gravel sheets, named as U1, U2 and U3 (Khan \& Sonakia, 1992) which concealed the Surajkund formation yellow sands (Figure 3). We recognized such stratigraphic successions of sheet-gravel in entire Central Narmada valley, which broadly provide a temporal framework from Middle Pleistocene to Upper Pleistocene. 
However, there has been a widespread misinformation and confusion that the calvarium was re-deposited in the U1 sheet-gravel, which questioned its half million antiquity and was likely re-deposited and dated to ca. $236 \mathrm{ka}$ (Patnaik et al., 2009).

The Narmada project led by the author as a Principal Investigator was liberally supported by the AnSI for five years during 2005-2010 close to his superannuation. It was only during 2005 exploration that Arun Sonakia accompanied our team of experts and field investigators (mentioned in acknowledgments) showed us the site of the calvarium and the author showed the site of the clavicles (Figure 4). It was on the Surajkund yellow sands concealed by the lowest unit of the cemented conglomerate sheet (U1), whereas the site of the clavicles and the rib fossils was above in the yellow sands underneath the U2 gravel sheet. Soon after, the author and his team excavated the submerged part of the U1 Surajkund yellow sands at Hathnora ghat for digging out a submerged mandible of Equus namadicus. While excavation was in operation under water, the author lifted up a large Acheulian handaxe, and went on collecting suchlike under water, and the collection rose to a surprising over 100 Acheulian large flake handaxes, cleavers and choppers within a few hours. The team also witnessed a half-submerged cranium of Equus namadicus and of the Hexaprotodon namadicus, which were

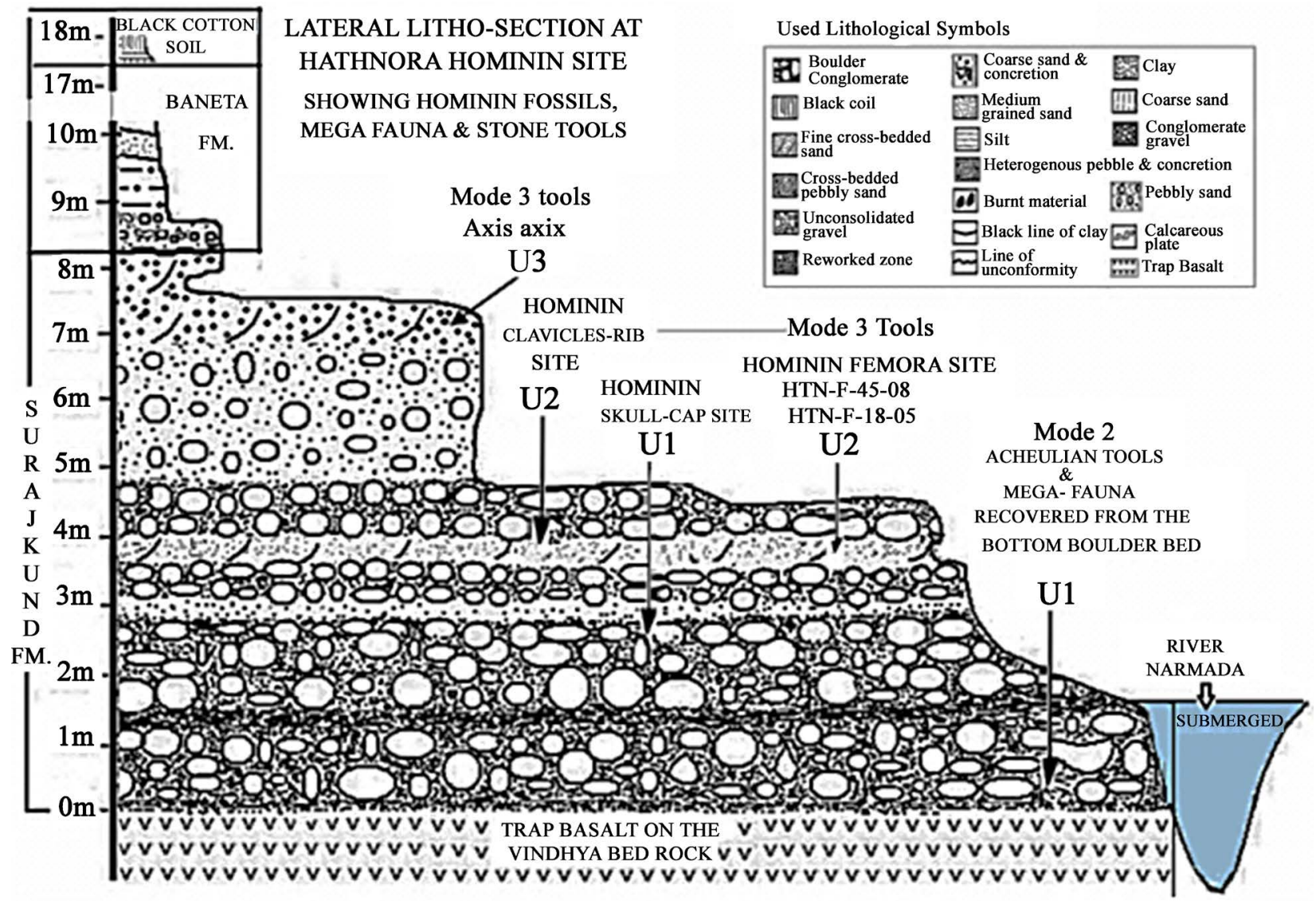

Figure 3. Hathnora lateral litho-section showing the hominin fossil sites and associated mammalian fauna and archaeological contexts. 


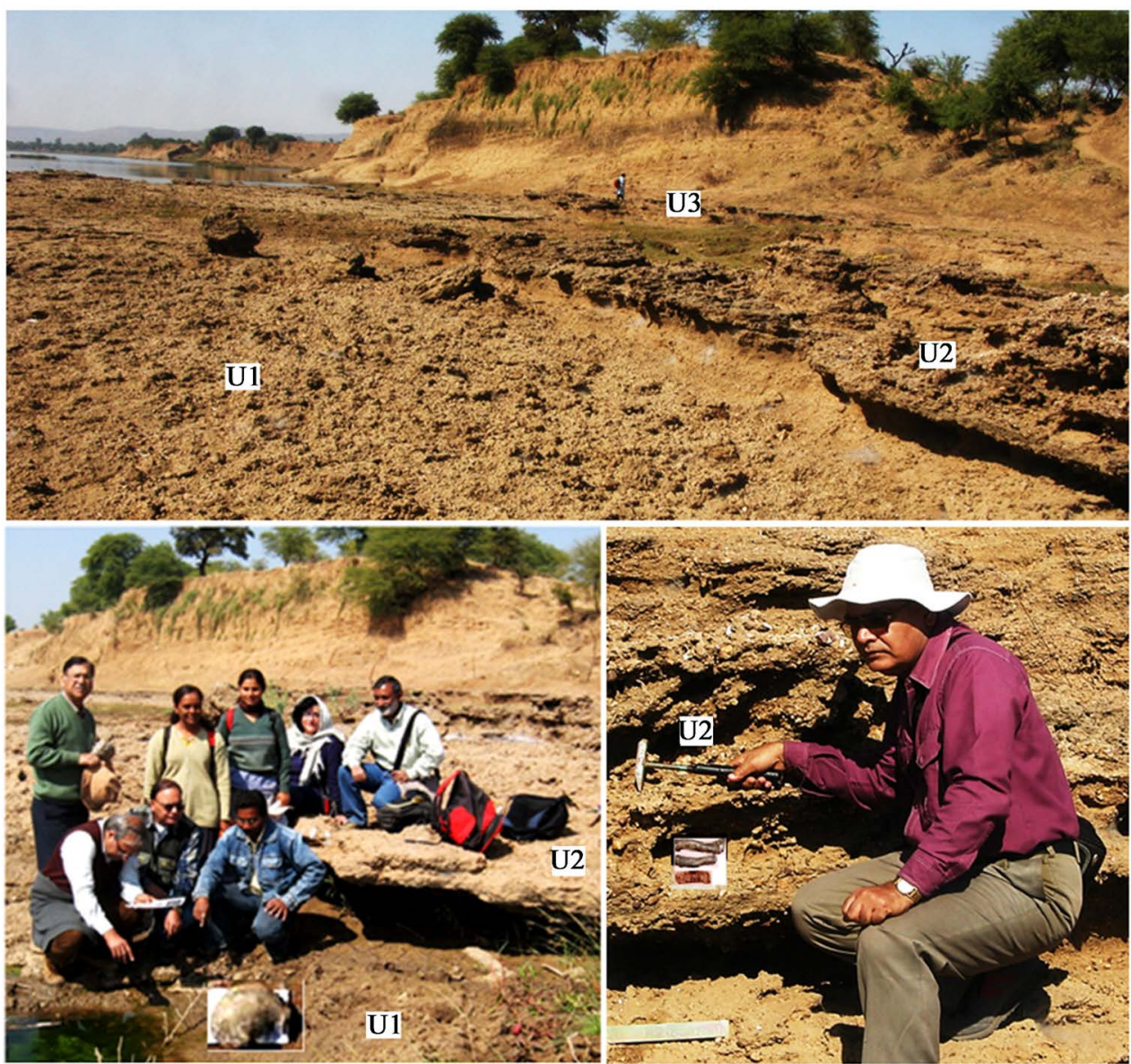

Figure 4. A general view of Hathnora hominin fossil locality (top); below the experts and field investigators witnessing the calvarium site in $\mathrm{U} 1$, and the author showing the clavicle site in $\mathrm{U} 2$ contexts.

dug out. The next day a villager lifted out a cranium of Bubalus namadicus with one complete long horn. Later, a cranium of Bos namadicus was also discovered from the partly submerged U1 bed. Such complete fossils of typical Middle Pleistocene megaterrestrial mammals, and typical large flake Acheulian tools were not previously accessible to earlier workers who collected only small flakes from surfaces of U1 and U2 gravel sheets (de Lumley \& Sonakia, 1985; Badam et al., 1986). Thus, it was for the first time that the bio-stratigraphic status of the calvarium was ascertained. Interestingly, an Acheulian implement was stuck in the hard matrix deposited on the Equus namadicus mandible, suggesting contemporaneity of the archaeological findings.

\section{The Hominin Findings}

The project was extended to the entire central Narmada basin from Jabalpur to Handia with a four-time repeat and the result was a fabulous accrual of about 1200 fossils and about 9000 stone tools, housed in the Palaeoanthropology Repository of the AnSI at Kolkata. The project was over in mid-2010 and with it the four-year tenure of the investigators too, including the superannuation of the 
author was near. The result was that the collections remained unstudied and partially catalogued. A hurried scrutiny by the author led to the discovery of a hominin femur and a humerus from Netankheri, a new locality, 3-km north-east of Hathnora calvarium site, reported in the year 2012 (Sankhyan et al., 2012a, 2012b).

After a gap of three years, the AnSI called the author as a Visiting Fellow to study, catalogue the fossil and archaeological collections and write reports on them, including similar Siwalik research work at the North-West Regional Centre at Dehradun. The author had submitted a 4-year plan for these tasks as per the normal tenure of the fellowship, but the succeeding officials limited the fellowship to half and couldn't let research work complete. The author could manage the scrutiny of the fossil collection and was lucky to have discovered nine more hominin postcranial fossils, namely, 5-femora, 2-humeri and 2-sacra. These were measured, scanned and photographed, but their detailed comparative study took one year after the fellowship leading to publication of three papers in the year 2017 (Sankhyan, 2017a, 2017b, 2017c). Thus, on date, there are 15 hominin fossils on record from the Narmada valley discovered from different localities and bio-stratigraphic and archaeological contexts, and pose a challenge to associate the bones with the calvarium. After a detailed morphometric study of the fossil bones, the present study is an attempt to sort out these into morphotypes using their robustness or gracility, estimated sex, stature or body size, and unique morphological traits under their stratigraphic control (Figure 5). The
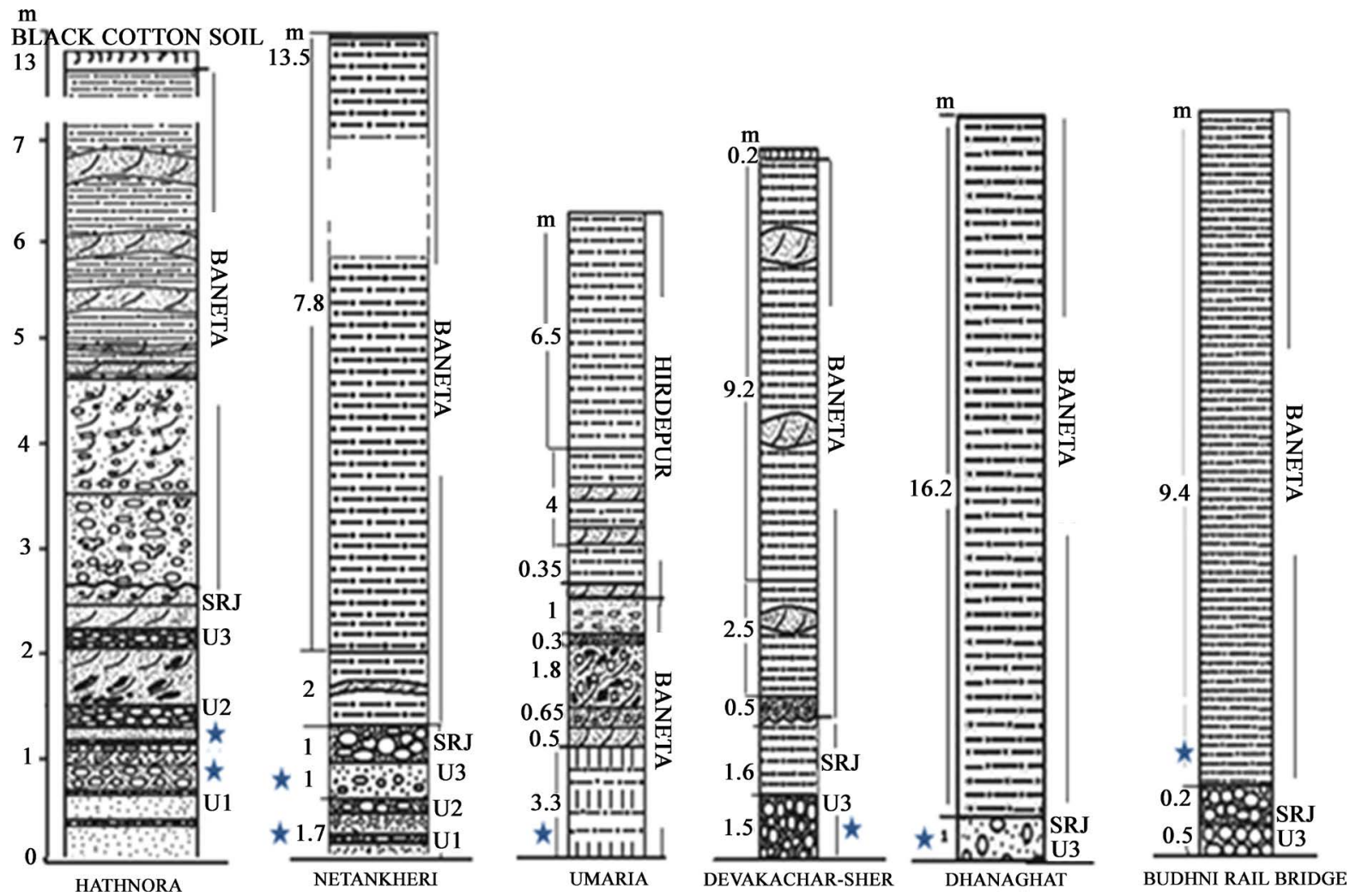

Figure 5. The vertical stratigraphic sections of the hominin-yielding sites in the central Narmada valley showing hominin fossils in stars. 
totality of evidence recognizes two main hominin morphotypes, discussed in the following pages.

\section{The Evidence for A "Robust” Tall Hominin}

Three fossils represent one single robust Acheulian hominin in the central Narmada valley, whose salient features are discussed.

\subsection{The Calvarium}

The skullcap (calvarium) was initially sexed as male due to great robusticity (10 $\mathrm{mm}$ cranial vault thickness: Figure 2: 1d), but later due to stubby mastoid process it was assigned to a female. It is heavily mineralized and indicates considerable antiquity. It preserves most of the right half from orbit, supraorbital ridge and frontal to the zygomatic unto the occipital, its base, the auditory meatus and the mastoid process. The left side includes only a bit along the mid-sagittal plane. The cranial base preserves the margin of the foramen magnum; the occipital bone is preserved and pitted by gravels; the sagittal and lambdoid sutures are traceable; the mid sagittal plane is slightly furrowed.

It invoked considerable interest in public and debate among scholars. The great robustness or thickness of the cranial vault, first indicated it a Homo erectus, which was further attested by a landmark morphometric study by M-A de Lumley in France. The study concluded that the calvarium belonged to an "evolved" Homo erectus (Lumley \& Sonakia, 1985), also maintained by another study (Mallasse, 2009). The second study conducted by Kenneth A.R. Kennedy in USA assigned the calvarium to "archaic" Homo sapiens (Kennedy 1989, 1999, 2000, 2007; Kennedy et al., 1991), presenting a great mosaic of H. erectus, H. sapiens and unique features, important of which are as follows:

$H$. erectus traits: (a) pentagonal vault, (b) flat base with maximum breadth at the supramastoid crest, (c) prominent postorbital constriction, (d) very stout torus angularis, (e) sagittal keeling, (f) thick cranial vault $(11 \mathrm{~mm})$, (g) strong petrous, (h) strongly developed occipital torus, (i) small mastoid process.

H. sapiens traits. (a) elevated cranial vault, (b) non-coincident bregma and vertex, (c) inion not coinciding with opisthocranion and well separated from endinion, (d) higher cranial capacity (1155-1421cc) compared to H. erectus (800 $-1200 \mathrm{cc}$ ) averaging at $1000 \mathrm{cc}$.

Unique traits. (a) the furrowed sagittal ridge, (b) large external auditory meatus (ear hole), (c) unusually long temporal bone. These are absent in erectus and modern sapiens and distinguish Narmada hominin at the trinomial level only (Kennedy, 2007).

All this makes the phylogenetic status of Narmada calvarium confusing. For those who lump all the Old World Middle Pleistocene transitory hominin fossils in a single widely occurring species, Homo heidelbergensis (Sankhyan, 2007; Rightmire, 1988, 1990, 1998; Athreya, 2007; Sankhyan, 2010, 2016), the Narmada calvarium eluded them as Homo heidelbergensis. Coming to the non-metric 
traits, a cladistic analysis (Cameron et al., 2004) removed the calvarium from Asian $H$. erectus fold and specifically regarded it akin to the European Steinheim Man, besides general resemblance to other European Middle Pleistocene hominins. However, a scrutiny of these non-metric traits and the various morphometric comparison by the author (Sankhyan, 2007) also endorses European affinity. The overall score of maximum affinity (within $\pm 5 \mathrm{~mm}$ ) is in the order of: Petralona (11), La Ferrassie (10), La Chapelle Aux Saints (8) classic Neanderthals, followed by Rhodesian man from Kabwe (7). The other African and Asian hominins show minimal affinities. In other words, Narmada hominin calvarium belonged to a "big-brained" species, Homo heidelbergensis or a similar "archaic" Homo sapiens than to Homo erectus sensu stricto. But, its considerable affinities with the classical Neanderthals are more a surprise and difficult to explain, except through hybridization. There is a great possibility of hybridization due to Narmada Valley's mid-intercontinental place in the Old World as a possible crossroad or corridor of early hominin migrations. This is very likely why the calvarium possesses a mosaic of characters. Its unique features may be explained as a result of considerable local evolution after hybridization as happened among the Neanderthal group of hominins in Europe.

\subsection{Postcranial Evidence for Robust Tall Hominin}

So far the Hathnora Narmada calvarium represents a robust hominin. We may look for robust postcranial fossils from Hathnora and nearby/adjoining localities of the same/equivalent horizon, along with associated archaeological and mammalian fossils. In this connection two femur fossils could be considered for the possible association, viz., (1) NTK-F-07-05-a left distal femur shaft from Netankheri and (2) GRL-F-16-06-a left femur distal shaft from Gurla (Sankhyan et al., 2012a, 2012b).

\subsubsection{The Left Distal Femur from Netankheri (NTK-F-07-05)}

The Netankheri, located $3 \mathrm{~km}$ upstream from Hathnora along the northern bank of the River Narmada, has a $19.2 \mathrm{~m}$ thick litho section, whose lower $3.7 \mathrm{~m}$ part is attributed to the Middle Pleistocene Surajkund Formation, and the remaining $15.5 \mathrm{~m}$ upper portion to the Upper Pleistocene Baneta Formation. As at Hathnora, the Surajkund Formation at Netankheri is comprised of three distinct cemented pebble conglomerate beds, denoted as U1, U2 and U3 with inter-layers of yellow sands. The cemented U1 remains submerged in River Narmada most of the time such that it remains largely unexplored and unmeasured exactly, except the sequences of yellowish brown coarse sand and pebbles above it. The $\mathrm{U} 2 / \mathrm{U} 3$ units of the cemented gravel here are collapsed and spread as a gravely sand bar for a longer distance. The collapsed segment contains the fragments of Vindhya sandstone and other volcanic materials, like chert, jasper, agate, etc. derived from the Satpura Hills, which served the raw material for the Middle to Upper Palaeolithic artefacts. The Baneta fine brown calcareous clayey silt with grey sand lenses and thick brown silty clay overlays disconformably. 
Netankheri left femur is $81 \mathrm{~mm}$ mineralized distal-most shaft portion of the femoral body or corpus femoris, detached from the condyles. It is typically cylindrical in shape, which broadens and flattens distally near the condylar region and forms a distinct well preserved triangular popliteal surface on its posterior aspect. The articular surface of the patellar deep notch and the intercondylar fossa are eroded. The lateral surface is rounded compared to the slightly pinched medial surface above the condyles, which flare medially when the femur is held perpendicularly. The femur, though limited by the degree of preservation, yet shows a notable feature of low development of the medial and lateral lips that results in a sub-circular/ovoid shape of the diaphysis in cross-section. In this respect it is unlike the modern human femur where the two lips emerge into linea aspera prominent ridges resulting in a posterior pilaster or flatness. In this respect the robust Netankheri femur is comparable to the robust and rounded femur of the Neanderthal which generally lacks the pilaster. Therefore, it may draw closer to the "late archaic" hominins (Carretero et al., 2009; Franciscus \& Churchill, 2002; Weaver, 2009), e.g. Tabun 3, Qafze 9 and Skhul 5. In the metric comparison the Netankheri femur draws closer to Homo heidelbergensis. The estimated stature for the Netankheri femur comes to $164.83 \pm 5 \mathrm{~cm}$ (male) $159.82 \pm 5 \mathrm{~cm}$ (female), which conforms to a medium tall robust male hominin.

The Faunal and Cultural Context. The Netankheri U1 level yielded only a few mammalian fossils; notably the molar fragments of Stegodon insignis ganesa, suggesting Middle Pleistocene age (Badam \& Sankhyan, 2009) for the Netankheri femur as for the Hathnora hominin calvarium. Only a few heavy-duty Acheulian implements were recovered from the Netankheri U1 level, which include a large pick. But, due to submergence, it remained largely unexplored. It is apparent that the Hathnora calvarium and the Netankheri femur are derived from a larger robust archaic $H$. sapiens sharing $H$. erectus and Homo neanderthalensis mosaic morphology or like a Homo heidelbergensis (Sankhyan et al., 2012a, 2012b).

\subsubsection{A Left Femur from Gurla (GRL-F-16-06)}

The femur comes from Gurla $\left(22^{\circ} 51^{\prime} 26^{\prime \prime N}\right.$ : $\left.77^{\circ} 52^{\prime} 08^{\prime \prime E}\right)$ located just opposite to Hathnora across the river Narmada along its left bank in District Hoshangabad. It is $10.4 \mathrm{~m}$ thick and similar to the Hathnora section in composition, comprising pebbly-sand $(1.2 \mathrm{~m})$ and conglomerated pebbles in the loose sand bar due to erosion of U1 and U2 of the gravel beds of the Surajkund Formation. It is overlain by dark brown concretionary silt containing thin sand lenses $(8.2 \mathrm{~m})$ of the Baneta Formation.

It is the distal shaft detached from the condyles, proximally preserved from the point where the lateral border flares out unto the lower half of the segment- 3 where the linea aspera divides into medial and lateral supracondylar lines. The corpus femoris (femoral body) is typically human-like cylindrical which broadens and flattens (pillaster) distally near the condylar region forming a distinct triangular popliteal surface on its posterior aspect. The two lips of the linea aspera are very prominent and blunt. It is elongated and narrow mediolaterally 
and posterior surface is flattish. It has an axial twist with distinct supracondylar lines form the two ridges of the linea aspera are indicative of a very robust man with weight-bearing legs. When the femur is held perpendicularly, the lateral surface looks larger and rounded compared to the narrow and pinched medial surface which flares more medially. The anterior surface is rounded and smooth, but posteriorly, the features are more prominent such as the deeper triangular popliteal surface enclosed by two prominent but blunt ridges of the linea aspera rising up and arching and drawing closer upwards.

The preserved $10.5 \mathrm{~cm}$ bone fragment yields a stature of $159.03 \mathrm{~cm}$ (for female), but considering its great robustness it belonged to a tall male of $164.08 \mathrm{~cm}$ height. In this respect it is similar to the Netankheri robust femur, and could be associated with the robust Hathnora calvarium.

The datum: An electron spin resonance (ESR) date (Cameron et al., 2004) of $>236$ kya fits within the biostratigraphic and cultural time of the findings, though linear uranium uptake show a confusingly wider range of $40-280 \mathrm{ka}$ (Patnaik et al., 2009). Considering the overall evidence we may tentatively keep the U1 hominin fossils, the Hathnora calvarium and the Netankheri femur at ca. 250 - $200 \mathrm{ka}$, whereas the U1/U2 Hathnora postcranial fossils at ca. 150 - $100 \mathrm{ka}$.

\section{Postcranial Evidence for "Short-Stocky" Hominin}

There are several fossil bones for this hominin discussed below.

\subsection{The Evidence from Two Clavicles}

The two tiny clavicle fossils were discovered from the U2 bed of the Surajkund Formation of Hathnora and sexed as adult female of 25 - 30 years age at death (Sankhyan, 1997a, 1997b, 2005) but show bilateral asymmetry due to left-sided ante mortem trauma. The locality name, similar age, and female sex of the clavicles and the calvarium evoked considerable interest and debate for about a decade (Sankhyan, 1999). A doctoral work (Sankhyan, 2010) presents detailed comparative morphometric analysis on the clavicles including estimation of the body dimensions of the hominin, the stature and the shoulder width by employing the databases of many studies (Flower, 1880; Parsons, 1916; Chatterjee, 1955; Gupta et al., 1960; Jit \& Singh, 1956; Vrba, 1979; Churchill, 2007; Pearson, 2000). The results indicate that the clavicles belong to a very "short and stocky" hominin with short shoulder width (= biacromial diameter) comparable to the Onge or Great Andaman Negrito pygmy (Sankhyan \& Rao, 2007). Their stature estimates ranged from $130-142 \mathrm{~cm}$ averaging at $138 \mathrm{~cm}$ worked out from a sample of 16 adult Onge females (Sankhyan \& Sahani, 2015). A similar estimate of $135 \mathrm{~cm}$ was worked out from a very large sample of modern clavicles (Jit \& Singh, 1956) that yielded regression value as: $Y=5.76 x+83.01 \mathrm{~cm}$, where $\mathrm{x}(9$ $\mathrm{cm}$ ) is the length of the Narmada right clavicle.

Since, the clavicle is a horizontal bone and potentially yields the thorax width across shoulders (= acromial diameter), Parsons's data (Parsons, 1916) on cla- 
vicle length and the shoulder width in English skeletons were utilized by the author to work out a regression: $\mathrm{Y}$ (shoulder width) $=201.647+1.160 \mathrm{x}$ (for the Right clavicle), where $\mathrm{x}(9 \mathrm{~cm})$ is the clavicle length of the Narmada right clavicle. It yielded $30.6 \mathrm{~cm}$ width which closely tallies with the mean biacromial diameter of the 29 Onge females $(31.2- \pm 1.1 \mathrm{~cm})$ having a narrow range (29 $33.5 \mathrm{~cm}$ ) (Carretero et al., 2009). Another sample of 16 adult Onge females also conform to the same findings, i.e., $30.14 \mathrm{~cm}$ mean (range $28-33 \mathrm{~cm}$ ), and the Sakai pygmy (Chatterjee, 1955) also show similar values $(33.5 \mathrm{~cm})$.

Another important feature of the clavicle studied was its mid-shaft index that exhibits a general evolutionary trend from flattened diaphyses (platycleidic) noticed in early African hominins and European Neanderthals (55 - 69.9) through intermediate rounding (mesocleidic) condition in some Neanderthals and Asian Homo erectus (70 - 84.9) to the rounded diaphyses (eurycleidic) in modern humans (>85). In this respect the Narmada clavicles $(\mathrm{R}=81.5, \mathrm{~L}=83.6)$ share this trend with E.R.-1808 Kenyan Homo habilis (Carretero et al., 2009) (83.3) which exhibits advance mesocleidic or the lower eurycleidic threshold of the Andaman pygmy and modern humans, and distances from the western European Neanderthals (96), who are "hyperpolar" adapted to cold climatic (Churchill, 2007).

\subsection{The Evidence from the $9^{\text {th }}$ Fossil Rib}

It shows typical human/hominin character of the $8^{\text {th }}$ to $10^{\text {th }}$ rib in being thinner and less twisted shaft with shallow and single costal groove, depressed tubercle, similar angle-tubercle distance, marked angle and M. scalenus posterior muscle scar behind the angle. It bears the peculiarities of the $9^{\text {th }}$ rib, namely, a large tubercle projecting below the inferior border, thicker and broader angle-tubercle region; shallower and broader costal groove, obliterated below the tubercle, rectangular non-articular part of the tubercle, etc. In its expanse, the fossil rib is similar to a pygmy $9^{\text {th }}$ rib or modern human $4^{\text {th }} / 5^{\text {th }}$ rib, again pointing towards a thorax scaled to a pygmy-size and reflected on similar ecological adaptations in consonance with the clavicles.

Thus, the tiny robust clavicles and the $9^{\text {th }}$ rib are a mismatch to the calvarium and revealed the additional presence of a hitherto unknown pygmy-sized archaic hominin species in the Narmada Valley, further confirmed by the additional postcranial fossils, excavated Palaeolithic tools and fauna.

\subsection{The Evidence from a Right Femur Mid-Shaft (HTN-F-18-05)}

While the Hathnora U1 stratigraphic bed yielded the calvarium, its $\mathrm{U} 2$ yielded two femoral portions (HTN-F-18-05 and HTN-F-45-08) at different times along the right bank of river Narmada in district Sehore. While the hominin calvarium was derived from its basal cemented conglomerate (U1) bed of the Surajkund Formation, the two femora were discovered from the overlying U2 cemented gravel bed, which has previously yielded two clavicles and a rib. Both femoral parts bear similar light brown coloration and mineralization, and are likely the 
parts of the same bone, though collected at different times. Regarding the dates of the Hathnora hominins, initially, a very wide range of dates of $\sim 650-75 \mathrm{ka}$ were suggested for the Surajkund Formation which contained the hominin remains. Later workers limited that to ca. $250 \mathrm{ka}$ for the Hathnora calvarium, but of late, some of them assumed a possibility of a wider range, 280 - $40 \mathrm{ka}$ (Patnaik et al., 2009) for the Hathnora calvarium; the youngest upper limit, however, makes no sense considering the highly mineralized skullcap and clavicles. Hence, unless new dates are forthcoming, it is worthwhile to depend upon the biostratigraphic ages of Middle to Late Pleistocene.

The proximal mid-shaft (HTN-F-18-05) preserves $12.8 \mathrm{~cm}$ long, comprising a bit of the Segment 2, the full Segment $3(7.5 \mathrm{~cm})$ and a little of the Segment 4 . It is mineralized and has cracks in middle and the lateral border is eroded along the pectineal curve by taphonomic agencies or gnawing by the carnivores indicated by an elongated dental depression. Proximally, the bone is broken at the base of the lesser tubercle below the lesser trochanter at its medial junction where the spiral line emanates and gives attachment to the pectineus muscle, and laterally at the gluteal tuberosity; it is the anatomically weak region liable to break. The pectineal line is distinctly curved ridge-like and forms the medial lip of the linea aspera. Dorsally it is convex and roughened by muscle lines anteriorly, and nearly cylindrical and slightly arched. The posterior (ventral) surface is typically flattened or concave and strengthened by two prominent longitudinal ridges of the linea aspera with intervening groove.

The author had earlier (Sankhyan, 2017c) estimated the hominin statures from the preserved segments of the femora and the humeri. HTN-F-18-05 femoral Segment 3 with correlation value 4.18 (Solan \& Kulkarni, 2013) yields total femur length $31.35 \mathrm{~cm}$, which gives statures of $131.53 \mathrm{~cm}$ (if female) but considering the robustness it is attributed to a male $(138.26 \pm 5 \mathrm{~cm})$, which again falls among the "short and stocky" individuals.

\subsection{The Evidence from a Right Femur Distal Shaft (HTN-F-45-08)}

It preserves only $1 / 4^{\text {th }}$ of the distal shaft, just $2.5 \mathrm{~cm}$ of the estimated $10 \mathrm{~cm}$ long Segment 4. It is mineralized and shares the coloration of the HTN-F-18-05 right femur, and likely represents its distal part from which the condyles have been detached off. The total femur length from $10 \mathrm{~cm}$ long segment 4 comes to 31.7 $\mathrm{cm}$ and statures $132.4 \mathrm{~cm}$ (female) and $139.07 \mathrm{~cm}$ (male). Similarity in the estimated statures reveals that both proximal and distal parts are derived from the same male individual, who was very "short and stocky". Interestingly, similar stature estimates for the Hathnora clavicles indicates that they could have been derived from the same "short and stocky" ("pygmoid") hominin population.

\subsection{The Evidence from a Left Humerus Shaft (NTK-F-02-07)}

It was recovered from U2/U3 stratigraphic level at Netankheri. The humerus was associated with several bone artefacts. The U2/U3 units of the cemented gravel 
here are collapsed and spread as a gravely sand bar. The collapsed segment contains fragments of Vindhya sandstone and other volcanic materials like chert, jasper, agate, etc. derived from the Satpura Hills, which serve as the raw material for the Middle to Upper Palaeolithic artefacts. The Baneta overlays disconformably as fine brown calcareous clayey silt with grey sand lenses and thick brown silty clay.

The Netankheri left humerus mid shaft, preserved below the radial sulcus (spiral groove) up to the upper margin of the olecranon fossa measures $84 \mathrm{~mm}$. It exhibits typical shape of the human humerus, cylindrical proximally, widening and turning prismatic distally. It is bounded by three borders and three surfaces, besides showing a medial bending or twisting on the posterior surface; this is where the brachialis narrows superiorly and widens distally. Distally, the posterior surface is flattish and covered by the lateral and medial heads of the tricep brachii that give origin to part of the brachialis (Sankhyan et al., 2012a, 2012b). There is a broad, shallow, oblique depression in the center. It is pertinent to know whether the NTK humerus is of the archaic hominins or of modern humans. Studies (Todd \& Churchill, 2006) show that the archaic/modern human dichotomy could be established by the proximal ulna, but this is not supported by the distal humeral morphology.

The humerus yielded an estimated maximum length of $240 \mathrm{~mm}$, which is even shorter than the mean length of five Chaurite humeri $(291.4 \pm 13.43 \mathrm{~mm})$ as well as from a larger sample of 33 mixed mainland Eastern Indians plus the Chaurite $(284.74 \pm 27.19 \mathrm{~mm})$. Interestingly, the NTK and Chaurite Nicobari population is shorter and stockier in the available comparative sample (Todd \& Churchill, 2006; Bermudez de Castro et al., 2012; Trinkaus, 2007; Trinkaus \& Ruff, 1999), which includes Omo Kibish and Cro-Magnon 1. As such the present specimen may only be suggested as "late archaic" human from its mineralization also shared with the associated bone tools, which are typo-technologically late Middle or early Upper Palaeolithic.

Faunal \& Cultural Contexts. The U2/U3 interface at Hathnora has yielded fossil fragments; we dug out an antler of the Axix axix at Hathnora. But, at Netankheri the U2/U3 has yielded the human humerus along with an isolated dentition of Equus hemionus khur. But, the important associations are with the bone implements discovered for the first time in Narmada Valley at Netankheri and Amkheri just on the opposite bank and at a few other localities with collapsed upper Surajkund gravel. They were found along with other lithic tools of quartzite, chert, chalcedony, jasper and agate. They are mostly of splintered bone fragments, which show marks of secondary chipping and intentional modifications resulting in shapes found among the Middle and Upper Palaeolithic industries. Some of the better recognized typo-technological categories found include, spatulas-cum-end scrapers, dagger, knifes, borers, awls, burins, blades, etc. and the bone implements recovered within the collapsed U2/U3 interface of the Surajkund Formation located below the Baneta Formation stratigraphic boundary. 
The datum: If we consider the YTA datum of 75 Kya of the Baneta and Hirdepur formations of the Central Narmada Valley, the humerus could be older or around $75 \mathrm{ka}$. This provides evidence for the adaptive continuity of the archaic short and stocky hominins and evolution to early modern $H$. sapiens, who likely formed the ancestral substratum for the later short-bodied populations of South Asia, including the pygmies.

\subsection{The Left Femur from Umaria (UMR-F-08-07)}

The section at Umaria is located at $\left.23^{\circ} 00^{\prime} 50^{\prime \prime} \mathrm{N}, 79^{\circ} 01^{\prime} 18^{\prime \prime} \mathrm{E}\right)$ on the right bank of river Umar, a tributary of Sher south of village Umaria in Narsingpur (=Narasimhapur) district. From the base upwards the about the half section is of the Baneta Formation and the remaining $(6.5 \mathrm{~m})$ of Hirdepur Formation. The fossil of UMR-F-08-07 left femur distal shaft has come from the bottom layer of the Baneta Formation, extensively exposed there, and could be dated to around 75 - 60 $\mathrm{ka}$ in consideration of the YTA signatures found within the Baneta Formation.

It is distal body shaft detached off the condyles. The bone shows evidence of mineralization and on the medial aspect of the upper body a small chip of the cortical bone is cut off likely due to taphonomic causes or eroded. The specimen shows a typical cylindrical shape of the hominin femoral body or corpus femoris, which broadens and flattens distally near the condylar region forming a distinct triangular popliteal surface on its posterior aspect where it is strengthened by two lips of longitudinal ridges of the linea aspera, which are quite prominent and blunt. Distally, the epiphyseo-diaphyseal condylar contact lines are more visible with their eversion in the middle towards the adductor tubercle medially.

The preserved bone $10.3 \mathrm{~cm}$ is a $66.67 \%$ part of the Segment-4, such that the complete segment 4 would be $15.45 \mathrm{~cm}$ which would yield total length of the femur as $30.43 \mathrm{~cm}$, and therefore, the stature $129.26 \mathrm{~cm}$ (female) and $136.13 \mathrm{~cm}$ (male). As the femur belongs to an archaic robust individual, so we may prefer a male stature of $136.13 \pm 5 \mathrm{~cm}$, which falls among the "short and stocky" early modern humans and at par with the Andaman pygmy.

\subsection{The Left Femur from Devakachar (DKC-F-05-09)}

It comes from Devakachhar Section (on river Sher), a tributary of river Narmada $\left(23^{\circ} 00^{\prime} 25^{\prime \prime} \mathrm{N}: 7^{\circ} 07^{\prime} 32^{\prime \prime} \mathrm{E}\right)$ between Umaria and Devakachhar in district Narsingpur (M.P.). The exposed section is $15.5 \mathrm{~m}$ thick of Surajkund Formation, disconformably overlain by the Baneta Formation comprised of quartz, chert, agate, jasper and few numbers of quartzite, etc., sealed by a $0.2 \mathrm{~m}$ thick black soil at the top. It is a $12.17 \mathrm{~cm}$ long distal body shaft detached from the condyles and preserves a bit of the Segment 3, the full Segment $4(9.7 \mathrm{~cm})$ and a bit of the condylar Segment 5 intact. Proximally, a chip of the cortical bone is deeply chipped off from the medial aspect; the bone is mineralized and patinated. The specimen is typical human femur with a cylindrical body, slightly arched and more convex in front anteriorly (dorsally) and slightly concave or flattish behind (ventrally). Due 
to patination the surface turned featureless, and the two lips of the linea aspera are indistinct, though the mCT scan reveals the cortical thickness along the length and elliptical distal cross section. The shaft shows distinct medial flair. The anterior (dorsal) surface is smooth, convex, and slopes medially thereby broadening the lateral surface, whereas the posterior (ventral) surface is nearly rounded but slightly flattened distally in the popliteal area. The gracility of the bone and non-muscular character indicates a young adult female. The total femoral length was estimated from the length of the Segment $4(9.7 \mathrm{~cm}) \times 3.17=$ $30.75 \mathrm{~cm}$, and accordingly the mean stature of the DKC individual comes to be: if female $=130.05 \mathrm{~cm}$; and if male $=136.87 \mathrm{~cm}$. Since, the gracility of the bone suggests a female, we may consider hominin as $130.05 \mathrm{~cm}$, which is quite "short and stocky" as that of Hathnora and Netankheri.

\subsection{The Left Humerus Midshaft from Dhanaghat (DHG-F-42-06)}

The Section at Dhanaghat that yielded the DHG-F-42-06 left humerus midshaft fragment is located at $22^{\circ} 49^{\prime} 50^{\prime \prime} \mathrm{N}: 77^{\circ} 58^{\prime} 29^{\prime \prime} \mathrm{E}$ along the left bank of Narmada under Babai sub-division of district Hoshangabad. It is an extensive sand bar of $16.2 \mathrm{~m}$ brown calcareous silt of the Baneta Formation. Only its base of one meter thickness is comprised of pebbly sand of U3 gravels of the Surajkund Formation which have yielded the humeral fragment. In consideration of the YTA limit a probable date of 75 - 60 ka could be assigned to the Dhanaghat humerus.

It is almost the complete Segment 3, retaining $7.2 \mathrm{~cm}$ mid fragment of the shaft (corpus humeri) with the medullary cavity visible and reinforced at the ends. The bone fragment is about a third of the way to the elbow where the humerus swells into the deltoid tuberosity, a triangular elevation that supports the insertion point of the deltoid muscle, marked by the coraco-brachialis medially. Its upper extent is up to the mid of the pectoralis major and teres major muscular region, just below the beginning of the lateral head of the triceps. It is typically the cylindrical upper humeral body part with the lateral and medial heads of the triceps enclosing a distinct radial sulcus or the spiral groove for the radial nerve. Only a little part of the lower body is preserved which reveals the distal widening, which turns prismatic below. We can notice a medial bend or distinct twist on the posterior surface of the mid-shaft body where the brachialis narrows upward medialward and widens downward lateralward. Nearly the whole of the body surface is covered by the lateral and medial heads of the Triceps brachii, the former arising above, and the latter below the radial sulcus, a broad but shallow oblique musculospiral groove or depression. The specimen bears mineral signatures of the Surajkund Fm U2/U3 cemented gravel showing dark colour and whitish grey patches of quartz depositions, suggesting considerable antiquity.

\subsection{Left Humerus from Budhni (BDG-F-04-07)}

The specimen was collected from the Baneta Formation and bears its brownish grey colour of the sediments with mineralization attesting younger antiquity. It 
is a $7.7 \mathrm{~mm}$ long mid-shaft fragment of the body shaft (corpus humeri) above the deltoid tuberosity and represents the complete Segment 3. It shows very little mid medial twist, indistinct muscular markings, slightly smaller size, more flattish posterior surface is flattish, indistinct spiral groove is; rounded and narrower lateral border.

The preserved Netankheri (NTK-F-02-07) humeral fragment is $8.4 \mathrm{~cm}$, which about $78 \%$ of the complete Segment 4, estimated to be $11.0 \mathrm{~cm}$ if fully preserved. The preserved fragments of other two humeri, DHG-F-42-06 and BDG-F-04-07, measure 7.2 and $7.7 \mathrm{~cm}$ respectively. But, their segments 3 are complete, which measure $6.6 \mathrm{~cm}$ and $6.8 \mathrm{~cm}$, respectively. Using the proportion of the segment 3 to the total humeral length (Kantha \& Kulkarni, 2014) (21.5\%) and of the segment 4 to total humeral length (37.3\%). The DHG-F-42-06 gives a stature of $148.66 \mathrm{~cm}$ for male and $142.82 \mathrm{~cm}$ for a female, suggesting medium tall archaic hominin. The BDG-F-04-07 also yielded a medium tall stature of $151.52 \mathrm{~cm}$ (for male) and $145.51 \mathrm{~cm}$ (for a female). Both Budnighat and Dhanaghat humeri appear to be of the females.

Thus, the "short and stocky" mode-3 archaic Homo sapiens, tentatively denoted by a new species Homo "narmadensis" (Sankhyan, 2013) may have been a product of local evolution or an early "African import" to South Asia via the Arabian Peninsula (Petraglia \& Alsharekh, 2003; James \& Petraglia, 2005; Petraglia, 2007) between 150 - 100 ka via Darri-I-Kur of northeastern Afghanistan (Angel, 1972). They survived the "volcanic winter" (Chesner et al., 1991; Ambrose, 1998; Oppenheimer, 2002, 2003; Rose \& Chesner, 1990) due to unique cultural adaptations, such as bone tool technology, which could have facilitated rapid attainment of anatomical modernity (Sankhyan, 2013). The recent mtDNA M-haplotype signatures $>60$ kya found in the Munda, Pauri Bhuiya (Barik et al., 2008; Chandrasekar et al., 2009; Mondal et al., 2016) inhabiting the eastern or Northeastern fringes of Narmada Valley, who interestingly, also share these signatures with the Andaman pygmies, likely attest continuity of the "short-bodied" populations. Similar later Upper Palaeolithic and Mesolithic hominin occupants extended to extreme South Asia 30 ka in the Fa Hien cave in Sri Lanka (Kennedy \& Deraniyagala, 1989) as well as, which would continue to fuel the debate on "continuity" versus "replacement". On the other hand, the Narmada-like Late Acheulian "robust tall morphotype" (cf. H. heidelbergensis) expanded to northward (Sankhyan et al., 2009; Sankhyan, 2020) and southeastward (Sankhyan et al., 2011). The palaeoenvironmental scenario with prevalence of warm climatic conditions (Kotlia \& Joshi, 2008) in the Narmada valley favoured continuity and diversity of "short-bodied" populations since the later Middle to Late Pleistocene. Very likely the "Volcanic Winter" made a little impact on the Narmada hominins who continued thereafter too (Haslam et al., 2011). They had extended to its Vindhya-Satpura confinements and had a safe haven in the numerous rock-shelters where they had "creative explosion" or developed "technological ingenuity" leading to development of rock-art, and even portable art as early as 
$40 \mathrm{ka}$ (Sankhyan, 2017d). The biological change responded to these cultural activities by shedding out the archaic adaptive morphologies, especially through hybridization. A recently excavated Acheulian site Tikoda in the Vindhya Range (Ota \& Deo, 2014) may reveal more secrets of human evolution.

Beyond the central Narmada valley, the well-dated older Acheulian sites of Peninsular India, such as Attirampakkam (Pappu et al., 2011), Isampur, Hunsgi and Baichbal (Paddayya, 2003, 2008), Morgaon and Bori (Westaway et al., 2011; Kailath et al., 2000; Misra et al., 1995) are attributed to Homo erectus on African analogy. Although fossils are yet awaited from these sites, it is apparent that Homo erectus was endemic in South India, which evolved further in the central Narmada valley, where it was also hybridized with western late Acheulian hominins, $H$. heidelbergensis. It was overtaken by the "short and stocky" $H$. "narmadensis" on the onset of the Middle Palaeolithic Mode 3, which may have origins within India as evident at Attirampakkam (Akhilesh et al., 2018). It showed adaptive continuity and survived the "Volcanic Winter", both in central India and southern India, and probably evolved and splitted to several short-bodied ancient Indian tribes, including the Andaman pygmy.

\section{General Evolutionary Scenario}

A summary of the nine long bone fossils, their dates, stratigraphic and archaeological contexts, and physical morphotypes based on sex, robustness, and estimated statures, and equivalent species, is presented in Table 1. Some data are added after James Harrod (personal communication).

1) Late Acheulian ( 250 - $150 \mathrm{ka}$ )

Hominin: U1 Hathnora, calvarium, "large-bodied" archaic with mosaic features', $H$. heidelbergensis//Petralona, paleontology and fauna $\sim 300-200 \mathrm{ka}$; note Petralona date is $\sim 200 \pm 50 \mathrm{ka}$ and by fauna, agree with a date of $\sim 250 \mathrm{ka}$.

2) Late Acheulian/EMP“Intermediate” ( 200 - $150 \mathrm{ka}$ )

Hominin: U2 Hathnora clavicles; stature $135 \mathrm{~cm}$ "small-bodied" archaic, $H$. "narmadensis", close to Andamanese, with light-duty refined "Acheulian or MP" tools.

Compare: Patpara III $140 \pm 11$; Sihawal I > $119 \pm 12$; Bamburi I Lower Sihawal, "Late Acheulian" $131 \pm$ 9; Bhimbetka III-F-23 L6-8 "terminal Acheulian" $106 \pm 20 \mathrm{ka}$; Thar Unit III “MP or Late Acheulian" 109 - $130 \mathrm{ka}$; FA/EMP Intermediate industries in Narmada-Son 140 - $110 \mathrm{ka}$, If (3) and (4) inferred, then two clades, a robust, medium height H.s.s. with robust features (= Skhul) and a small-bodied $H$. "narmadensis" (=Andaman) co-occur; the co-occurrence continues through MP into UP and recent times.

3) Early Middle Palaeolithic ( 150 - $100 \mathrm{ka}$ )

Hominins: U1 Netankheri femur, stature $\sim 160 \mathrm{~cm}$, It fits well with Hathnora calavaria mosaic of $\mathrm{H}$. erectus and Neanderthal $=H$. heidelbergensis, H.s.s.//Skhul 5;

Hominins: U1/U2 Gurla femur, "very robust individual of medium height $\sim 164$ cm" Compare: Sihawal I, Middle Son, $113 \pm$ 19; Bhimbetka III-F-23 L5; 
Table 1. Hominin long bone fossils with catalogue numbers, their cultural, faunal \& chronological contexts, and morphotypes, species \& equivalents.

\begin{tabular}{|c|c|c|c|c|c|}
\hline $\begin{array}{l}\text { SR } \\
\text { NO. }\end{array}$ & $\begin{array}{l}\text { CATALOGUE NO. \& } \\
\text { FOSSIL }\end{array}$ & $\begin{array}{l}\text { FM., STRATUM \& } \\
\text { DATUM }\end{array}$ & $\begin{array}{l}\text { MORPHOTYPE } \\
\text { (SEX, SHAPE \& } \\
\text { STATURE) }\end{array}$ & $\begin{array}{l}\text { CULTURAL \& FAUNAL } \\
\text { CONTEXT }\end{array}$ & SPECIES \& EQUIVALENT \\
\hline 1 & $\begin{array}{l}\text { NTK-F-07-05 } \\
\text { femur left distal shaft }\end{array}$ & $\begin{array}{l}\text { Surajkund U1 = calvarium, } \\
250-200 \mathrm{ka}\end{array}$ & $\begin{array}{l}\text { male tall } \sim 160 \mathrm{~cm} \\
\text { archaic robust }\end{array}$ & $\begin{array}{l}\text { Acheulian pick; Stegodon } \\
\text { ganesa }\end{array}$ & $\begin{array}{l}\text { mosaic } H \text {. erectus, } H . \text { hei- } \\
\text { delbergensis Neanderthal, } \\
\text { H.s.s.//Skhul }\end{array}$ \\
\hline 2 & $\begin{array}{l}\text { GRL-F-16-06 } \\
\text { femur left distal shaft }\end{array}$ & $\begin{array}{l}\text { Surajkund U1 = calvarium } \\
250-200 \mathrm{ka}\end{array}$ & $\begin{array}{l}\text { Male, tall } \sim 164 \mathrm{~cm} \\
\text { archaic robust }\end{array}$ & $\begin{array}{l}\text { Acheulian handaxe, cleaver } \\
\text { Equus namadicus }\end{array}$ & Archaic H.s.s \\
\hline 3 & $\begin{array}{l}\text { HTN-F-18-05 } \\
\text { femur right proximal } \\
\text { shaft }\end{array}$ & $\begin{array}{l}\text { Surajkund U2 = clavicles } \\
\sim 150 \mathrm{ka}\end{array}$ & $\begin{array}{l}\text { Female, } 138 \mathrm{~cm} \text { archaic } \\
\text { short -stocky }\end{array}$ & $\begin{array}{l}\text { Late Acheulian } \\
\text { Middle Palaeolithic } \\
\text { flakes, Axix axix }\end{array}$ & $\begin{array}{l}\text { H. “narmadensis" } \\
\text { Par Pygmy }\end{array}$ \\
\hline 4 & $\begin{array}{l}\text { HTN-F- } 45-08 \\
\text { femur left distal shaft }\end{array}$ & $\begin{array}{l}\text { Surajkund U2 } \\
=\text { clavicles } \sim 150 \mathrm{ka}\end{array}$ & $\begin{array}{l}\text { Female, } 138 \mathrm{~cm} \text { archaic } \\
\text { short -stocky }\end{array}$ & $\begin{array}{l}\text { Late Acheulian } \\
\text { Middle Pal, flakes, Axix axix }\end{array}$ & $\begin{array}{l}\text { H. "narmadensis" } \\
\text { Par Pygmy }\end{array}$ \\
\hline 5 & $\begin{array}{l}\text { DKC-F-05-09 } \\
\text { femur left distal shaft }\end{array}$ & $\begin{array}{l}\text { Surajkund U3 } \\
=\text { YTA, } 75 \mathrm{ka}\end{array}$ & $\begin{array}{l}\text { Female, } 135 \mathrm{~m} \text { gracile } \\
\text { early modern short } \\
\text {-stocky }\end{array}$ & $\begin{array}{l}\text { Middle Palaeolithic } \\
\text { flake tools }\end{array}$ & $\begin{array}{l}\text { H. “narmadensis" } \\
\text { Par Pygmy }\end{array}$ \\
\hline 6 & $\begin{array}{l}\text { UMR-F-08-07 femur } \\
\text { left distal shaft }\end{array}$ & $\begin{array}{l}\text { Surajkund U3 } \\
=\text { YTA, } 75 \mathrm{ka}\end{array}$ & $\begin{array}{l}\text { Male, } 136 \mathrm{~cm} \\
\text { archaic robust short - } \\
\text { stocky }\end{array}$ & $\begin{array}{l}\text { Middle Palaeolithic } \\
\text { flake tools }\end{array}$ & $\begin{array}{l}\text { H. "narmadensis" } \\
\text { Par Pygmy }\end{array}$ \\
\hline 7 & $\begin{array}{l}\text { NTK-F-02-07 humerus } \\
\text { left distal shaft }\end{array}$ & $\begin{array}{l}\text { Surajkund U3 } \\
=\text { YTA, } 75 \mathrm{ka}\end{array}$ & $\begin{array}{l}\text { ?male, } 144.93 \mathrm{~cm} \\
\text { ?female } 139.33 \mathrm{~cm} \\
\text { archaic short -stocky }\end{array}$ & $\begin{array}{l}\text { Middle Palaeolithic } \\
\text { Flake and bone tools, Equus } \\
\text { hemionus khur }\end{array}$ & $\begin{array}{l}\text { H. "narmadensis" } \\
\text { Par Pygmy }\end{array}$ \\
\hline 8 & $\begin{array}{l}\text { DHG-F-42-06 } \\
\text { humerus left mid-shaft }\end{array}$ & $\begin{array}{l}\text { Surajkund U3 } \\
=\text { YTA, } 75 \mathrm{ka}\end{array}$ & $\begin{array}{l}\text { ? male, } 148.66 \mathrm{~cm} \\
\text { ? female } \\
142.82 \mathrm{~cm} \text {, archaic } \\
\text { medium tall }\end{array}$ & $\begin{array}{l}\text { Middle Palaeolithic } \\
\text { Flake and bone tools, }\end{array}$ & $\begin{array}{l}\text { H. “narmadensis" } \\
\text { Par Pygmy }\end{array}$ \\
\hline 9 & $\begin{array}{l}\text { BDG-F-04-07 } \\
\text { humerus left mid-shaft }\end{array}$ & $\begin{array}{l}\text { Baneta Lower } \\
=40 \mathrm{ka}\end{array}$ & $\begin{array}{l}\text { ? male, } 151.52 \mathrm{~cm} \\
\text { ? female, } 145.51 \mathrm{~cm} \\
\text { medium Tall }\end{array}$ & $\begin{array}{l}\text { Middle Palaeolithic } \\
\text { Flake and bone tools, }\end{array}$ & $\begin{array}{l}\text { Modern } \\
\text { H. sapiens }\end{array}$ \\
\hline
\end{tabular}

Thar Unit II MP with diminutive bifaces 40 - 80; if Skhul, then 130 - $100 \mathrm{ka}$ ? This is distinct Skhul clade H.s.s. with robust features possibly out-of Africa diffusion.

4) Late Middle Palaeolithicl EUP

Hominin: U2/U3 Netankheri Humerus; stature 132.4 - 139 cm (male) "moderately short and stocky" late archaic/H.s.s., culture blades, flakes, bone tools, $\sim 74$ ka Toba; U2 Dhanaghat humerus, stature $142.82-148.66 \mathrm{~cm}$, medium tall archaic: U2 Hathnora femur fragments, $\sim 150 \mathrm{ka}$; stature $132.4-139.07 \mathrm{~cm}$.

Compare: Earliest microlithic UP in Narmada Basin, Mehtakheri $\sim 48 \pm 2$ ka; Bhimbetka III-F-23 L4 (OSL) $45 \pm 8$ ka; Toba fits find location better. Possibility is of these intermediate stature people an admixture of the two clades.

\section{5) Later Upper Palaeolithic}

Hominin: Budni humerus, Baneta Fm. (bottom), 40 ka (Patnaik et al., 2009); stature: 145 - $152 \mathrm{~cm}$ (medium tall modern); hominin: Umaria femur, Baneta Fm. (bottom) $40 \mathrm{ka}$ (Patnaik et al., 2009); stature stocky 129 - $136 \mathrm{~cm}$ (short-stocky: par pygmy), Compare: Bhimbetka III-F-23 L3, Mesolithic, microliths. 


\section{Conclusion}

Present findings would have several implications in understanding human evolution in South Asia. The analysis presented here indicates presence of two main types of early archaic hominins in central Narmada Valley during Middle to Late Pleistocene. The "large robust" hominin attributed to Homo heidelbergensis, was widespread during Middle Pleistocene at lower Surajkund at U1 stratigraphic level, dated to 250 - $150 \mathrm{ka}$. It hunted the mega mammalian fauna with typical large flake Acheulian mode-2 implements. The "short and stocky" hominin appeared Surajkund at U2 stratigraphic level, likely datable $\sim 150-100 \mathrm{ka}$ and hunted relatively small game animals using refined late Acheulian and Middle Palaeolithic mode-3 implements, during later Middle Pleistocene. It showed evolutionary continuity to modernity and branched off to several short-bodied populations of Indian mainland, including the Andaman pygmy.

\section{Acknowledgements}

As Principal Investigator of the Narmada project, the author thanks V.R. Rao, the then director for liberal facilities, and the experts G.L. Badam, S.B. Ota, M.P. Tiwari, Y.H. Bhai and Shanti Pappu for field orientations to the young investigators, namely, L.N. Dewangan, Sheuli Chakraborty, Shashi Prabha, Suvenu Kundu, D.P. Haldar, Jhilika Pal, Robin Chatterjee and Rana Chakraborty (all credited elsewhere). He thanks K.K. Basa, D.K. Bhattacharya (late), S.R. Walimbe, V. Shinde, and M.L.K. Murthy (late) for time-to-time advice, and G.S. Rautela, later director, for providing the author an opportunity of a Visiting Fellow to study the material at Kolkata that made this study possible.

\section{Conflicts of Interest}

The author declares no conflicts of interest regarding the publication of this paper.

\section{References}

Acharyya, S. K., \& Basu, P. K. (1993). Toba Ash on the Indian Subcontinent and Its Implications for the Correlation of Late Pleistocene Alluvium. Quaternary Research, 40, 10-19. https://doi.org/10.1006/qres.1993.1051

Agrawal, D. P., Kotlia, B. S., \& Kusumgar, S. (1988). Chronology and Significance of the Narmada Formations. Proceedings of Indian national Science Academy, 54A, 418-424.

Akhilesh, K., Pappu, S., Rajapara, H. M., Gunnell, Y., Shukla, A. D., \& Singhvi, A. K. (2018). Early Middle Palaeolithic Culture in India around 385 - 172 ka Reframes out of Africa Models. Nature, 554, 97-101. https://doi.org/10.1038/nature25444

Ambrose, S. N. (1998). Late Pleistocene Human Population Bottlenecks, Volcanic Winter, and Differentiation of Modern Humans. Journal of Human Evolution, 34, 623-651. https://doi.org/10.1006/jhev.1998.0219

Angel, J. L. (1972). A Middle Paleolithic Temporal Bone from Darra-i-Kur, Afghanistan. In L. Dupree (Ed.), Prehistoric Research in Afghanistan (1959-1966). Transactions of American Philosophical Society (Vol. 62, pp. 54-56). Philadelphia, PA: American Philosophical Society.

Athreya, S. (2007). Was Homo heidelbergensis in South Asia? A Test Using the Narmada 
Fossil from Central India. In M. D. Petraglia, \& B. Allchin (Eds.), The Evolution and History of Human Populations in South Asia (pp. 137-170). New York: Springer Press. https://doi.org/10.1007/1-4020-5562-5_7

Badam, G. L., \& Sankhyan, A. R. (2009). Evolutionary Trends in Narmada Fossil Fauna. In A. R. Sankhyan (Ed.), Asian Perspectives on Human Evolution (pp. 92-102). New Delhi: Serials Publications.

Badam, G. L., Ganjoo, R. K., Salahuddin, M., \& Rajaguru, S. N. (1986). Evaluation of Fossil Hominin-The Maker of Late Acheulean Tools at Hathnora, Madhya Pradesh, India. Current Science, 55, 143-145.

Barik, S. S., Sahani, R., Prasad, B. V. R., Endicott, P. et al. (2008). Detailed mtDNA Genotypes Permit a Reassessment of the Settlement and Population Structure of the Andaman Islands. American Journal of Physical Anthropology, 136, 19-27.

https://doi.org/10.1002/ajpa.20773

Bermudez de Castro, J. M., Carretero, J. M., Garcia-Gonzalez, R., Rodri-guez-Garcia, L., Martinon-Torres, M., Rosell, J., Blasco, R., Martın-Frances, L., Modesto, M., \& Carbonell, E. (2012). Early Pleistocene Human Humeri from the Gran Dolina-TD6 Site (Sierra de Atapuerca, Spain). American Journal of Physical Anthropology, 147, 604-617.

https://doi.org/10.1002/ajpa.22020

Cameron, D., Patnaik, R., \& Sahni, A. (2004). The Phylogenetic Significance of the Middle Pleistocene Narmada Hominin Cranium from Central India. International Journal of Osteoarchaeology, 14, 419-447. https://doi.org/10.1002/oa.725

Carretero, J. M., Haile-Selassie, Y., Rodríguez, R., \& Arsuaga, J. L. (2009). A Partial Distal Humerus from the Middle Pleistocene Deposits at Bodo, Middle Awash, Ethiopia. Anthropological Science, 117, 19-31. https://doi.org/10.1537/ase.070413

Chandrasekar, A., Kumar, S., Sreenath, J. et al. (2009). Updating Phylogeny of Mitochondrial DNA Macrohaplogroup M in India: Dispersal of Modern Human in South Asian Corridor. PLoS ONE, 4, e7447. https://doi.org/10.1371/journal.pone.0007447

Chatterjee, B. K. (1955). A Comparative Study of the Different Body Proportions of the Onges of Little Andamans. The Anthropologist, 2, 12-21.

Chesner, C. A., Rose, W. I., Drake, A. D. R., \& Westgate, J. A. (1991). Eruptive History of Earth's Largest Quaternary Caldera (Toba, Indonesia) Clarified. Geology, 19, 200-203. https://doi.org/10.1130/0091-7613(1991)019<0200:EHOESL >2.3.CO;2

Churchill, S. E. (2007). Endocrine Models of Skeletal Robusticity and the Origins of Gracility. In A. R. Sankhyan, \& V. R. Rao (Eds.), Human Origins, Genome and People of India (pp. 337-368). New Delhi: Allied Publishers.

de Lumley, H., \& Sonakia, A. (1985). Contexte stratigraphique et Archéologique de L'Homme de le Narmada, Hathnora, Madhya Pradesh, Inde. L'Anthropologie, 89, 3-12.

Flower, W. H. (1880). On the Osteology and Affinities of the Natives of the Andaman Islands. Journal of Anthropological Institute (London), 9, 10-135. https://doi.org/10.2307/2841966

Franciscus, R. G., \& Churchill, S. E. (2002). The Costal Skeleton of Shanidar 3 and a Reappraisal of Neandertal Thoracic Morphology. Journal of Human Evolution, 42, 303-356. https://doi.org/10.1006/jhev.2001.0528

Gupta, P., Basu, A., \& Gupta, A. (1960). A Study on Onge Skeletons from Little Andaman, Part 1 \& 2. Bulletin Department of Anthropology (Govt. of India), 9, 27-40 and 81-106.

Haslam, M., Clarkson, C., Roberts, R. G., Bora, J., Korisettar, R., Ditchfield, P. et al. (2011). A Southern Indian Middle Palaeolithic Occupation Surface Sealed by the $74 \mathrm{ka}$ Toba Eruption: Further Evidence from Jwalapuram Locality 22. Quaternary Interna- 
tional, 258, 148-164. https://doi.org/10.1016/j.quaint.2011.08.040

James, H. V. A., \& Petraglia, M. D. (2005). Modern Human Origins and the Evolution of Behavior in the Later Pleistocene Record of South Asia. Current Anthropology, 46, 3-27. https://doi.org/10.1086/444365

Jit, J., \& Singh, S. (1956). Estimation of Stature from Clavicle. Indian Journal of Medical Research, 44, 137-156.

Kailath, A. J., Rao, T. K. G., Dhir, R. P., Nambi, K. S. V., Gogte, V. D., \& Singhvi, A. K. (2000). Electron Spin Resonance Characterization of Calcretes from Thar Desert for Dating Applications. Radiation Measurements, 32, 371-383. https://doi.org/10.1016/S1350-4487(99)00282-6

Kantha, L., \& Kulkarni, R. (2014). Estimation of Total Length of Humerus from Its Fragments in South Indian Population. International Journal of Anatomy and Research, 2, 213-220.

Kennedy, K. A. R. (1989). The Fossil Hominin from the Narmada Valley: Homo erectus or Homo sapiens. In C. Jarrige (Ed.), South Asian Archeology (pp. 145-152). Madison, WI: Prehistory Press.

Kennedy, K. A. R. (1999). The Paleoanthropology of South Asia. Evolutionary Anthropology, 8, 157-194. https://doi.org/10.1002/(SICI)1520-6505(1999)8:5<165::AID-EVAN5>3.0.CO;2-0

Kennedy, K. A. R. (2000). God-Apes and Fossil Men: The Paleoanthropology of South Asia. Ann Arbor, MI: The University of Michigan Press. https://doi.org/10.3998/mpub.16180

Kennedy, K. A. R. (2007). The Narmada Fossil Hominid. In A. R. Sankhyan, \& V. R. Rao (Eds.), Human Origins, Genome and People of India (pp. 188-192). New Delhi: Allied Publishers.

Kennedy, K. A. R., \& Deraniyagala, S. U. (1989). Fossil Remains of 28,000 Year Old Hominids from Sri Lanka. Current Anthropology, 30, 394-399. https://doi.org/10.1086/203757

Kennedy, K. A. R., Sonakia, A., Chiment, J., \& Verma, K. K. (1991). Is the Narmada Hominin an Indian Homo erectus? American Journal of Physical Anthropology, 86, 475-496. https://doi.org/10.1002/ajpa.1330860404

Khan, A., \& Sonakia, A. (1992). Quaternary Deposits of Narmada with Special Reference to the Hominid Fossil. Journal of the Geological Society of India, 39, 147-154.

Kotlia, B. S., \& Joshi, M. (2008). Reconstruction of Late Pleistocene Palaeoecology of the Upper Narmada Valley (Central India) Using Fossil Communities. Palaeoworld, 17, 153-159. https://doi.org/10.1016/j.palwor.2008.06.006

Lumley, M. A., \& Sonakia, A. (1985). Premiere Découverte D’un Homo erectus Sur Le Continent Indien a Hathnora, Dans la Moyenne vallée de la Narmada. L'Anthropologie, 89, 13-61.

Mallasse, A. D. (2009). Cranial Embryogeny and Hominin Phylogeny. In A. R. Sankhyan (Ed.), Asian Perspectives on Human Evolution (pp. 103-121). New Delhi: Serials Publications.

Misra, S., Venkatesan, T. R., Rajaguru, S. N., \& Somayajulu, B. L. K. (1995). Earliest Acheulian Industry from Peninsular India. Current Anthropology, 36, 847-851. https://doi.org/10.1086/204442

Mondal, M., Casals, F., Xu, T., Dall’Olio, G. M., Pybus, M., Netea, M. G., Comas, D., Laayouni, H., Li, Q., Majumder, P. P., \& Bertranpetit, J. (2016). Genomic Analysis of the Andamanese Provides New Insights into the Spread of Humans in Asia and Their 
Local Adaptations. Nature Genetics, 48, 1066-1070. https://doi.org/10.1038/ng.3621

Oppenheimer, C. (2002). Limited Global Change Due to Largest Known Quaternary Eruption, Toba 74 Kyr BP. Quaternary Science Review, 21, 1593-1609. https://doi.org/10.1016/S0277-3791(01)00154-8

Oppenheimer, C. (2003). Ice Core and Palaeoclimatic Evidence for the Great Volcanic Eruption of 1257. International Journal of Climatology, 23, 417-426. https://doi.org/10.1002/joc.891

Ota, S. B., \& Deo, S. G. (2014). Investigation of Acheulian Localities TKD-I and TKD-II at Tikoda, District Raisen, Madhya Pradesh (2010-12). In K. Paddayya, \& S. G. Deo (Eds.), Recent Advances in Acheulian Culture Studies in India (pp. 57-66). Pune: Indian Society for Prehistoric and Quaternary Studies.

Paddayya, K. (2003). Recent Findings on the Acheulian of Isampur Excavations and Its Dating. Current Science, 84, 127-128.

Paddayya, K. (2008). Evolution within the Acheulean in India: A Case Study from the Hunsgi and Baichbal Valleys, Karnataka. Bull. Dec. Coll. PG and Res. Institute, 66-67, 95-111.

Pappu, S., Yanni, G., Kumar, A., Régis, B., Maurice, T., François, D., \& Nicolas, T. (2011). Early Pleistocene Presence of Acheulian Hominins in South India. Science, 331, 1596-1599. https://doi.org/10.1126/science.1200183

Parsons, F. G. (1916). On the Proportions and Characteristics of the Modern English Clavicle. Journal of Anatomy, 51, 71-93.

Patnaik, R., Chauhan, P. R., Rao, M. R., Blackwell, B. A. B., Skinner, A. R., Sahni, A., Chauhan, M. S., \& Khan, H. S. (2009). New Geochronological, Paleoclimatological and Paleolithic Data from the Narmada Valley Hominin Locality, Central India. Journal of Human Evolution, 56, 114-133. https://doi.org/10.1016/j.jhevol.2008.08.023

Pearson, O. M. (2000). Activity, Climate and Postcranial Robusticity: Implications for Modern Human Origins and Scenarios of Adaptive Change. Current Anthropology, 41, 569-605. https://doi.org/10.1086/317382

Petraglia, M. D. (2007). Middle Paleolithic Assemblages from the Indian Subcontinent before and after the Toba Super-Eruption. Science, 317, 114-116.

https://doi.org/10.1126/science.1141564

Petraglia, M. D., \& Alsharekh, A. (2003). The Middle Paleolithic of Arabia: Implications for Modern Human Origins, Behaviour and Dispersals. Antiquity, 77, 671-684. https://doi.org/10.1017/S0003598X00061639

Rao, K. V., Chakraborti, S., Rao, K. J., Ramani, M. S. V., Marathe, S. D., \& Borkar, B. T. (1997). Magnetostratigraphy of Quaternary Fluvial Sediments and Tephra of Narmada Valley, Central India. Geol. Surv. Ind., Spl. Pub, 46, 65-78.

Rightmire, G. P. (1988). Homo erectus and Later Middle Pleistocene Humans. Annual Review of Anthropology, 17, 239-259. https://doi.org/10.1146/annurev.an.17.100188.001323

Rightmire, G. P. (1990). The Evolution of Homo erectus: Comparative Anatomical Studies of an Extinct Human Species. Cambridge: Cambridge University Press. https://doi.org/10.1017/CBO9780511525674

Rightmire, G. P. (1998). Human Evolution in the Middle Pleistocene: The Role of Homo heidelbergensis. Evolutionary Anthropology, 6, 218-227. https://doi.org/10.1002/(SICI)1520-6505(1998)6:6<218::AID-EVAN4>3.0.CO;2-6

Rose, W. I., \& Chesner, C. A. (1990). Worldwide Dispersal of Ash and Gases from Earth's Largest Known Eruption: Toba, Sumatra, 75 Ka. Palaeogeography, Palaeo-Climatology, 
Palaeoecology, 89, 269-275. https://doi.org/10.1016/0031-0182(90)90068-I

Sankhyan, A. R. (1997a). Fossil Clavicle of a Middle Pleistocene Hominid from the Central Narmada Valley, India. Journal of Human Evolution, 32, 3-16. https://doi.org/10.1006/jhev.1996.0117

Sankhyan, A. R. (1997b). A New Human Fossil Find from the Central Narmada Basin and Its Chronology. Current Science, 73, 1110-1111.

Sankhyan, A. R. (1999). The Place of Narmada Hominin in the Jigsaw Puzzle of Human Origins. Gondwana Geological Magazine Special Publication, 4, 335-345.

Sankhyan, A. R. (2005). New Fossils of Early Stone Age Man from Central Narmada Valley. Current Science, 88, 704-707.

Sankhyan, A. R. (2007). Significance of Human Postcranial Fossils from Narmada with Remarks on the Skullcap. In A. R. Sankhyan, \& V. R. Rao (Eds.), Human Origins, Genome \& People of India: Genomic, Palaeontological \& Archaeological Perspectives (pp. 193-217). New Delhi: Allied Publishers, Pvt. Ltd.

Sankhyan, A. R. (2010). Pleistocene Hominins \& Associated Findings from Central Narmada Valley Bearing on the Evolution of Man in South Asia. PhD Thesis, Chandigarh: Panjab University.

Sankhyan, A. R. (2013). The Emergence of Homo sapiens in South Asia: The Central Narmada Valley as Witness. Human Biology Review, 2, 136-152.

Sankhyan, A. R. (2016). Hominin Remains from the Narmada Valley, Chapter 6. In G. Robbins Schug, \& S. R. Walimbe (Eds.), Companion to South Asia in the Past (pp. 72-85). Hoboken, NJ: John Wiley \& Sons, Inc. https://doi.org/10.1002/9781119055280.ch6

Sankhyan, A. R. (2017a). Pleistocene Hominin Fossil Femora and Humeri. International Journal of Anatomy and Research, 15, 4510-4518.

https://doi.org/10.16965/ijar.2017.386

Sankhyan, A. R. (2017b). First Record and Study of Prehistoric Sacra from Central Narmada Valley (M.P.). International Journal of Anatomy and Research, 5, 4144-4151. https://doi.org/10.16965/ijar.2017.270

Sankhyan, A. R. (2017c). Statures of Prehistoric Humans from Fossil Femora and Humeri. International Journal of Forensic Science \& Pathology, 5, 341-346. https://doi.org/10.19070/2332-287X-1700075

Sankhyan, A. R. (2017d). Hitherto Unknown Pleistocene Portable Art from India. International Journal of Current Research, 9, 57562-57566.

Sankhyan, A. R. (2020). Human Evolution in South Asia and Implications for Northeast India, Chapter 24. In M. K. Chauley, \& M. Hazarika (Eds.), Archaeology in Northeast India Recent Trends and Future Prospects Essays Celebrating 150 Years of Research (pp. 1-15). New Delhi: Research India Press.

Sankhyan, A. R., \& Rao, V. R. (2007). Did Ancestors of the Pygmy or Hobbit Ever Live in Indian Heartland? In E. Indriati (Ed.), Recent Advances on Southeast Asian Paleoanthropology and Archeology (pp. 76-89). Yogyakarta: Gadjah Mada University.

Sankhyan, A. R., \& Sahani, R. (2015). The Andaman Pygmy: Origins and New Adaptations. In A. R. Sankhyan (Ed.), Recent Discoveries and Perspectives in Human Evolution (pp. 5-15). BAR International Series 2719, England: Archeo Press.

Sankhyan, A. R., Badam, G. L., Dewangan, L. N., Chakraborty, S., Prabha, S., Kundu, S., \& Chakravarty, R. (2012a). New Postcranial Hominin Fossils from the Central Narmada Valley, India. Advances in Anthropology, 2, 125-131.

https://doi.org/10.4236/aa.2012.23015 
Sankhyan, A. R., Dewangan, L. N., Chakraborty, S., Prabha, S., Kundu, S., \& Rao, V. R. (2009). Re-Looking at Prehistoric Susunia, West Bengal. In A. R. Sankhyan (Ed.), Asian Perspectives on Human Evolution (pp. 154-158). New Delhi: Serials Publications.

Sankhyan, A. R., Dewangan, L. N., Chakraborty, S., Prabha, S., Kundu, S., Chakravarty, R., \& Badam, G. L. (2012b). New Human Fossils and Associated Findings from the Central Narmada. Current Science, 103, 1-9.

Sankhyan, A. R., Dewangan, L. N., Sahoo, R. H., Chakravarty, R., \& Chatterjee, R. (2011). Early Prehistoric Signatures of Man in Bastar Region, Central India. Current Science, 101, 1146-1149.

Solan, S., \& Kulkarni, R. (2013). Estimation of Total Length of Femur from Its Fragments in South Indian Population. Journal of Clinical and Diagnostic Research, 7, 2111-2115. https://doi.org/10.7860/JCDR/2013/6275.3465

Sonakia, A. (1984). The Skullcap of Early Man and Associated Mammalian Fauna from Narmada Valley Alluvium, Hoshangabad Area, M.P. (India). Records Geological Survey of India, 113, 159-172.

Tiwari, M. P., \& Bhai, H. Y. (1997). Quaternary Stratigraphy of the Narmada Valley. Geological Survey of India Special Publication, 46, 33-63.

Todd, R. Y., \& Churchill, S. E. (2006). Archaic and Modern Human Distal Humeral Morphology. Journal of Human Evolution, 51, 603-616. https://doi.org/10.1016/j.jhevol.2006.07.006

Trinkaus, E. (2007). Appendicular Robusticity and the Paleobiology of Modern Human Emergence. Proceedings of the National Academy of Sciences of the United States of America, 94, 13367-13373. https://doi.org/10.1073/pnas.94.24.13367

Trinkaus, E., \& Ruff, C. B. (1999). Diaphyseal Cross-Sectional Geometry of Near Eastern Middle Paleolithic Humans: The Femur. Journal of Archaeological Science, 26, 409-424. https://doi.org/10.1006/jasc.1998.0343

van Heteren, A. H., \& Sankhyan, A. R. (2009). Hobbits and Pygmies: Trends in Evolution. In A. R. Sankhyan (Ed.), Asian Perspectives on Human Evolution (pp. 172-187). New Delhi: Serials Publications.

Vrba, E. S. (1979). A New Study of the Scapula of Australopithecus africanus from Sterkfontein. American Journal of Physical Anthropology, 16, 351-377.

Weaver, T. D. (2009). The Meaning of Neandertal Skeletal Morphology. Proceedings of the National Academy of Sciences of the United States of America, 106, 6028-16033. https://doi.org/10.1073/pnas.0903864106

Westaway, R., Mishra, S., Deo, S. G., \& Bridgland, D. R. (2011). Methods for Determination of the Age of Pleistocene Tephra, Derived from Eruption of Toba, in Central India. Journal of Earth System Science, 120, 503-530.

https://doi.org/10.1007/s12040-011-0087-0

Westgate, J. A., Shane, P. A. R., Pearce, N. J. C., Perkins, W. T., Korisettar, R., Chesner, C. A., Williams, M. A. J., \& Acharyya, S. K. (1998). All Toba Tephra Occurrences across Peninsular India belong to 75,000 Years B.P. Eruptions. Quaternary Research, 50, 107-112. https://doi.org/10.1006/qres.1998.1974 